\title{
Joyful And Meaningful Learning In Mathematics Classroom Through Internet Activities
}

\author{
Sitti Maesuri Patahuddin \\ State University of Surabaya \\ $<$ s@maesuri.com>
}

\begin{abstract}
This paper arises from the author experiences over the last eight years with regards to investigating how the Internet could be used as a tool for mathematics learning, mathematics teaching as well as for professional development. This paper illustrates three main categories of the potential of the Internet for learning: the Internet for information, the Internet for communication, the Internet for collaboration, followed by a description on how the use of the Internet could make learning mathematics interesting and meaningfully. Lastly, through the use of a case study and my experiences working with group of students using the Internet, I argue that the success of integrating the Internet into mathematics teaching and learning depends very much on teachers' knowledge and their philosophical beliefs about learning and teaching, learners, mathematics, and technology.
\end{abstract}

Keywords: Internet for communication, Internet for collaboration, Internet for learning, meaningful learning, teacher knowledge, beliefs.

\section{Introduction}

The genesis of my investigation about Internet for learning came firstly from my personal experiences. I found that the Internet had been a significant medium to achieve my objectives, namely to improve my qualities as a lecturer, a researcher, and a facilitator for mathematics teachers. This was primarily because in a situation where I lacked learning resources (e.g., current books and journals), the Internet enabled me to find many valuable resources, and even allowed me to communicate with several experts in other countries (e.g., sharing teaching and learning experiences, asking for online references). It has been meaningful and joyful learning experiences for me. This has motivated me to encourage others to take advantages from the accessibility of the Internet (see e.g., Ernawati \& Patahuddin, 2009; Patahuddin, 2007; Patahuddin \& Rokhim, 2009; Patahuddin, Rokhmah, \& Nur, 2010; Rokhim \& Patahuddin, 2010; Rokhmah, Patahuddin, \& Nur, 2010). This paper focuses on the potential of the Internet as a tool for meaningful and joyful mathematics learning.

\section{What Is The Internet And Its Potential?}

The Internet is not one place or one company. It is a descriptive term for a web of thousands of interconnected broad-band and narrow-band telephone, satellite, and wireless networks built on existing and planned communication technology. This infrastructure is a network of networks, reaching out and connecting separate islands of computer, telephone, and cable resources into a seamless web (Gattiker, 2001; p. 3).

The citation above shows us the sophistication of current technology which has become part of people's lives. It can be categorised into three main functions: the Internet for 
information, the Internet for communication, the Internet for collaboration. All these can be linked to mathematics education and has the potential advantages and limitations of the Internet in enhancing mathematics teaching and learning.

\section{The Internet for Information}

A wide range of information can be found through the Internet such as information from online books, atlases, newspapers, journals, magazines, dictionaries, radio or television programs, and so on. The Internet, supported by multimedia and good networks, can have multiple functions, for instance, serving as a radio, as a television, as a video, as well as a virtual visiting speaker. The Internet has opened broad opportunities for more communities to access information relatively instantly, regionally, nationally, and internationally. The Internet has also become increasingly familiar to more and more people due to its userfriendliness. Unfortunately, because nobody owns the Internet, anybody is able to post reliable, but also non-reliable information via the Internet. Through the Internet, users can be provided, not only with up-to-date information, but also out-of-date information. Internet users must also be aware of its instability, as information that is available now can be unavailable at any time in the future.

The literature has identified the Internet as a source of information, highlighting potential advantages and disadvantages for educational purposes. For example, Glavac (2004) described three useful websites for teachers and students, that may even be useful for parents, that contain many different educational topics on different subjects, including mathematics. One of the websites has been created by teachers for teachers. Engelbrecht and Harding (2005), in their attempt to classify mathematical sites on the Internet for undergraduate students, have also provided several examples of sites for mathematical enrichment, mathematical visualisation, sites that provide mathematical exercises for practice, quizzes, Olympiad questions, as well as information about full-online courses from a range of universities. Byerly and Brodie (2004) have provided a list of almost thirty mathematical websites, providing a brief description of their contents. Ameis and Ebenezer (2000) have written a book entitled "Mathematics on the Internet, A resource for K-12 Teachers", which includes practical information about using the Internet, a discussion on how mathematics learning can be facilitated via the Internet, and which also provides links to mathematical teaching resources and sites for professional development.

\section{The Internet for Communication}

The Internet increasingly has become popular as a means of communication at a regional, national, and global level. There are different ways that communication is enabled through the Internet, including via electronic mail (e-mail), mailing lists, online discussions or conferences, bulletin boards, chat rooms, Facebook, MySpace, Friendster, Twitter, Skype, 
and so on. The Internet as a communication tool is distinct from other forms of communication, such as the telephone, telegram, air mail, or face-to-face communication as users are able to send or receive messages relatively instantly and are able to send messages simultaneously to recipients around the globe. Recipients of messages can also benefit from this flexibility because they are able to check their e-mail or participate in discussion forums anytime, anywhere. All these features have opened opportunities to build up learning communities among Internet users from all over the world. However, these positive features can be outweighed by negative features, such as making users vulnerable to receiving harmful messages from unknown senders.

Engelbrecht and Harding (2005) have described sites (e.g., Math Forum) which enable users to share ideas, ask mathematics questions or get answers to mathematic problems, and access links to mathematical resources. Newell, Wilsman, Langenfeld, and McIntosh (2002) described how mathematics teachers from distant areas are communicating with other teachers instantly via the Internet instead of waiting for face-to-face communication at conferences. Further, Frid (2002) described how students benefited from communicating mathematical ideas with other students from different schools in different countries.

\section{The Internet for Collaboration}

Collaboration usually involves more than one person, or a group, working together to achieve particular goals. It requires communication between members and usually requires all members to be present at a site at some point. Lack of communication among members will inhibit the effectiveness of collaboration. With the Internet, communication has become increasingly easier, cheaper and even more effective. By using the Internet, people at a distance are able to undertake a project together in a virtual site. Thus, the Internet has clearly opened many opportunities to enable people from all over the world to collaborate.

Chausis (2002), a technology trainer, presents her ideas about tele-collaboration, that is by using the Internet tools and online resources to work together with people in different places. She introduces several Listserv resources, websites that provide opportunities for teachers to interact with other teachers via the Internet, and provide more specific websites to support collaboration between teachers for classroom activities such as TeacherLine, NickNacks Telecollaboration, Teacher-to-Teacher Collaboration, and so on. In the Teacherto-Teacher Collaboration website, a great number of websites can be found that provide opportunities for teacher professional development.

Clark (2000) highlights the potential of the Internet as an aid to collaboration and reveals several methods to facilitate and stimulate collaboration in online environments. He argues that collaboration is a solution of a problem caused by disadvantages of using the Internet for communication; it is "the loss of student interaction and friendships" (p.8). According to Clark, collaborative skills can be fostered by using e-mails, class bulletin 
boards, online conferences, gated conferences and so on, as well as by involving participants in discussions, group projects, and group papers.

Generally speaking, it has been widely accepted that the Internet has advantages and disadvantages as a source of information, as a medium of communication and as a site for collaboration. The rapid growth of the Internet should motivate researchers or educators to explore ways to optimise the use of the Internet for teaching and learning.

\section{Internet Activities for Joyful and Meaningful Mathematics Learning}

Several important questions are how Internet technology can assist teaching and learning to enable students to learn mathematics joyfully and meaningfully? What mathematical websites that are feasible to use for this purpose? This section, is trying to answer those questions.

The Internet can assist in supporting individual learning needs as well as assist learners in developing skills and knowledge. The Internet provides opportunities for students to engage with more dynamic forms of mathematics with multi-representations of mathematics concepts than those traditionally displayed in textbooks (see for example in http://illuminations.nctm.org; http://www.beenleigss.eq.edu.au). The role of knowing different representation of a particular concept in mathematics is to enhance conceptual understanding (Alagic, 2003; Crawford \& Evelyn, 2003) and this means potentially meaningful for learners (Wiske, Sick, \& Wirsig, 2001). As a result, teachers need to be aware of the influence these different representations have on the way students decode information.

Crawford \& Evelyn (2003, p. 172) argues that:

\footnotetext{
Digital manipulatives can be appropriately and successfully integrated into a mathematical learning environment through the use of web-based materials. [this use] provides an interactive environment with immediate feedback to explore indepth mathematical theories that would be difficult to stimulate with concrete models. Additionally, younger students are able to "see" (conceptualize) concepts that would normally be regulated to indepth abstract mathematical principles.
}

Moor and Zaskis (2000) found that "the interactive aspect of the Internet holds the attention of the student much longer than a regular page of information such as is found in a textbook (p. 103). They also found that words expressed by 25 of 36 students to describe their experiences in using the Web, are such as "fun”, "exciting”, entertaining”, "interesting”. Loong's study (2012) also “points to the potential of the Internet to motivate students. Interactive web objects that animate or can be virtually manipulated, and provide feedback to students seem to engage and motivate students” (p. 358). This finding indicates that students found using the Web to learn mathematics motivational. In other words, this is potentially joyful for learners.

The Internet could be used for a range of classroom activities, including direct access to learning objects and manipulatives, exploring investigations by students, comparing and 
communicating ideas with others, finding research on mathematical ideas, exploring lesson ideas, and also for accessing to community resources and excursion activities. In the following paragraphs, I briefly describe several websites in terms of what they look like, the mathematical concepts involved and how these activities engaged the students joyfully and meaningfully.

\section{Fido Puzzle}

The Fido puzzle (Figure 1) is an interactive game where the computer will "read the user's mind" (see http://www.digicc.com/fido/). In this game, the Internet users need to click through screens that instruct them, first to write down a 3 or 4 digit numbers, then to jumble the digits to make another number. Then they are instructed to subtract the smaller number from the larger one. Next, they are asked to draw a circle around one of the digits in their answer without letting the computer "see" the answer. Finally the Internet users are instructed to jumble the answer and type the number into the computer, excluding the number they circled. The computer then gives them the number they circled.

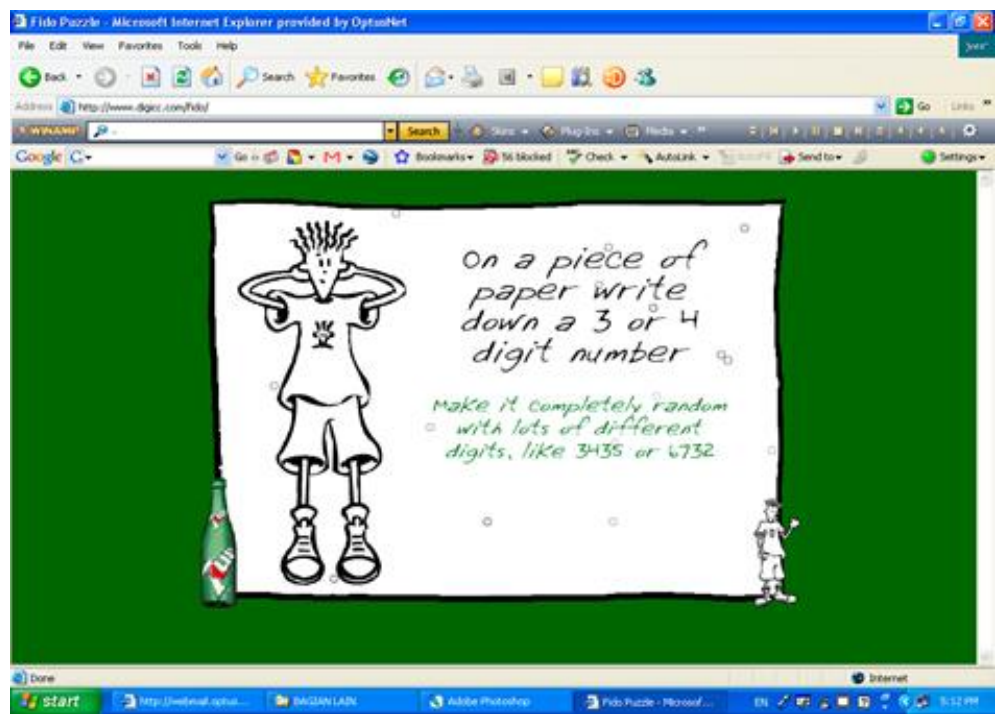

Figure 1. A page from Fido Puzzle website

In my study in one classroom in Australia, through the observation, I saw two pairs of students very excited about how the computer could know the number they were hiding. A pair of students was thrilled when they found that the computer was wrong and they reported to the teacher proudly that they could win. In fact, they did the wrong computation. They went back to check their computation after the teacher said that the computer was never wrong. At another time, I saw a student being helped by his peer. With the Fido Puzzle, it appeared that some students were learning a lot about computation in an engaging and motivating virtual game situation that required them to reflect upon their own thinking and calculation strategies. This Internet activity seemed to foster a dynamic learning of several students in the computer groups. 


\section{Geometry}

The geometry website (http://illuminations.nctm.org/) in figure below, which is provided by National Council of Teachers of Mathematics (NCTM, 2005), allows students to explore the properties of various geometric solids, such as the number of faces, edges, and vertices. The teacher can also formulate his/her own questions to suit the students' age and ability. This website was used by students in one classroom I studied in Australia through rotational activities and a group of students in Surabaya. This website was used to assist students to look at the features of different geometrical shapes and finding relationship between their components.

My experiences observing or working with students using this website, I found that students could easily navigate this website. It was a tool for students to observe different solid shapes since it allowed students to turn around the solid, to colour the faces of three dimensional figures. It appears to me that this "manipulatives website" is potential to develop students' mathematical thinking compared to the uses of physical models and the printed visual model. I also found from my observation in an Australian class and Indonesian groups of students that the students appeared to be on task and engaged in their learning joyfully and meaningfully using this geometric website.

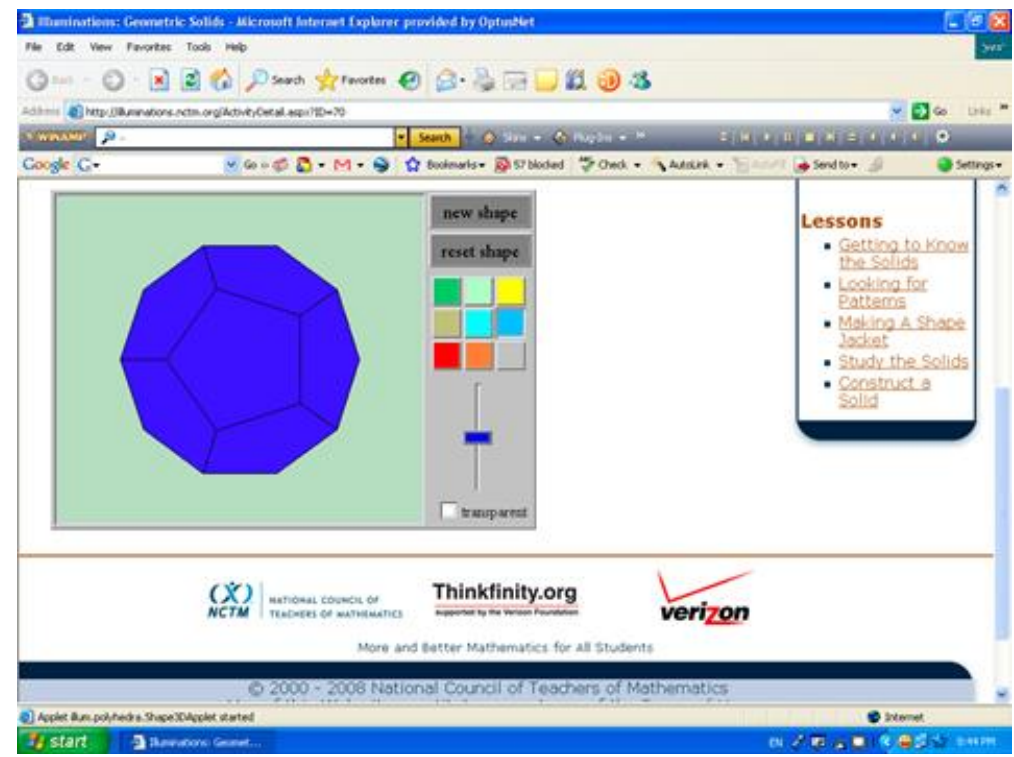

Figure 2. A page from Geometry website

\section{Learning about time}

There are many websites about "Time". One that I identified was called "Stop the clock" (Figure 3). The picture in the screen showed five clocks set in analogue time and five boxes set in digital time. The instruction asked the user to drag the five digital times to the correct analogue times and then press "STOP THE CLOCK" to check the answer and to show how long the user took. I found there were three levels of difficulty in this exercise. In Level 
1, the times were set at either the hour or the half hour. In Level 2, the times were set at either half hour or at quarter hourly intervals. In Level 3, the times were in five minute intervals.

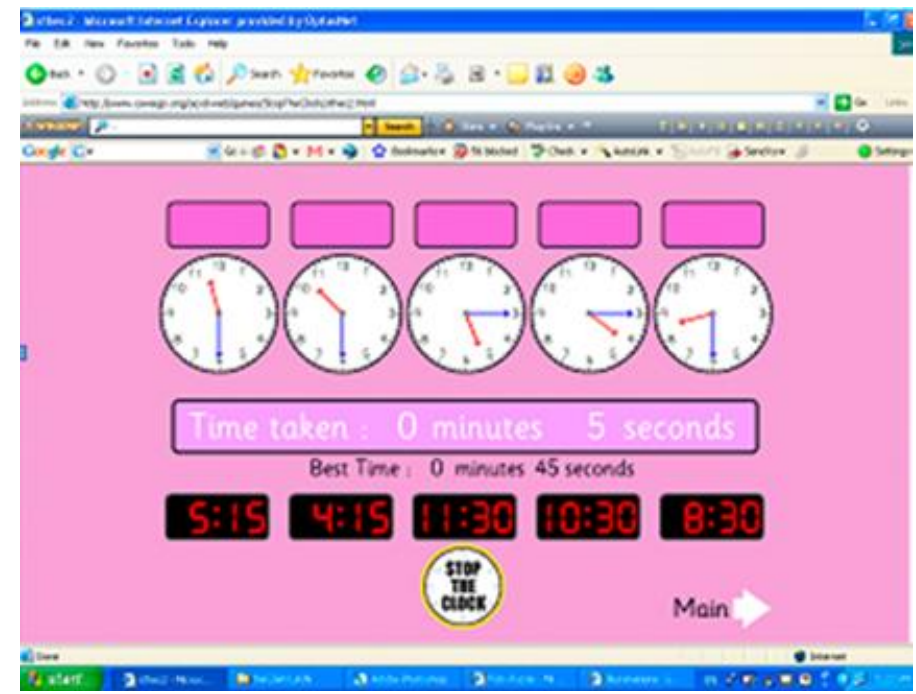

Figure 3. A page from a website "Stop the clock"

I also found other games such as "Set the Clock" (Figure 4) in which the user has to click the arrow to demonstrate on a clock face the hour given in words; a matching game (Figure 5) where the user has to match the time on the clock with digital time or words; and a game requiring deep concentration in which the user has to match the hidden times that appear when cards are flipped by clicking.
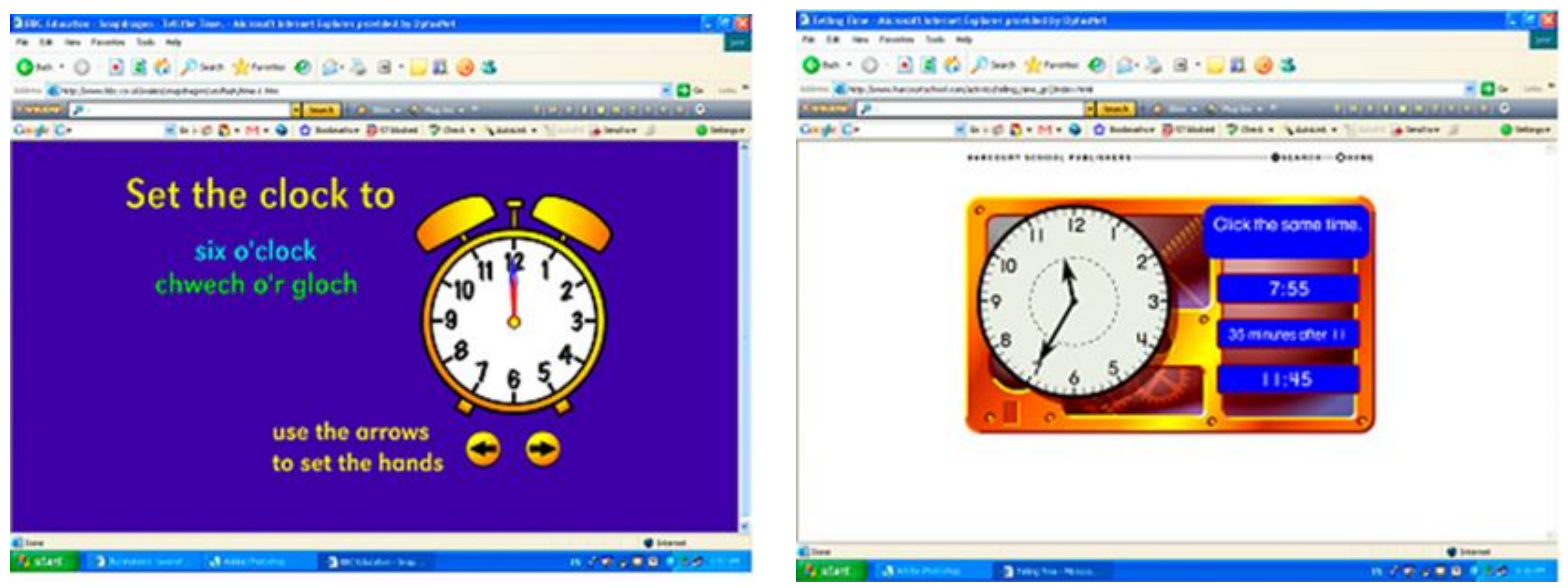

Figure 4. A page from a website "Set the clock" Figure 5. A page of matching game

My field notes described what occurred when I offered the clock websites to Grade 2 students in Australia.

I worked with four students using the websites on two computers. The four students worked in pairs. I facilitated them to do Level 1; the students worked out the problem and in just several minutes most of these students could match the digital clock and the analogue clock very quickly: many of them said "it's getting easy." They asked, "Can we go to the next level?” I let them click Level 2. With some discussion amongst the four 
students, they eventually solved the problems quickly. Several minutes after that, students commented that Level 2 was getting easier. They agreed to go to Level 3. With a little help from me, they could do the tasks at this level very well. Eventually, students asked permission to do the matching game.

Some other students came to see this learning and asked for a chance to do the computer activity. They looked curious and interested and one commented on these websites by saying "Cooooooool." One of the students touched the mouse, indicating that he wanted to have a turn in doing the Internet activities. While I facilitated the students with the website for about 20 minutes, their teacher continued his teaching about addition strategies. [27/04/06]

During this Internet activity, the students were very enthusiastic. They engaged in discussion and worked out the problem in pairs. They seemed to be challenged by the different levels and variety of the websites. I could see students were capable of higher level tasks than their teacher indicated when he checked the websites.

\section{Geography and Computations skills}

Another online game I found in which students could practise mathematics at different levels is shown in figure 6. This could be used to give students an opportunity to learn mathematics while playing games, or that this website could also be appropriate for students for extension work. Some other websites will be presented in the symposium.

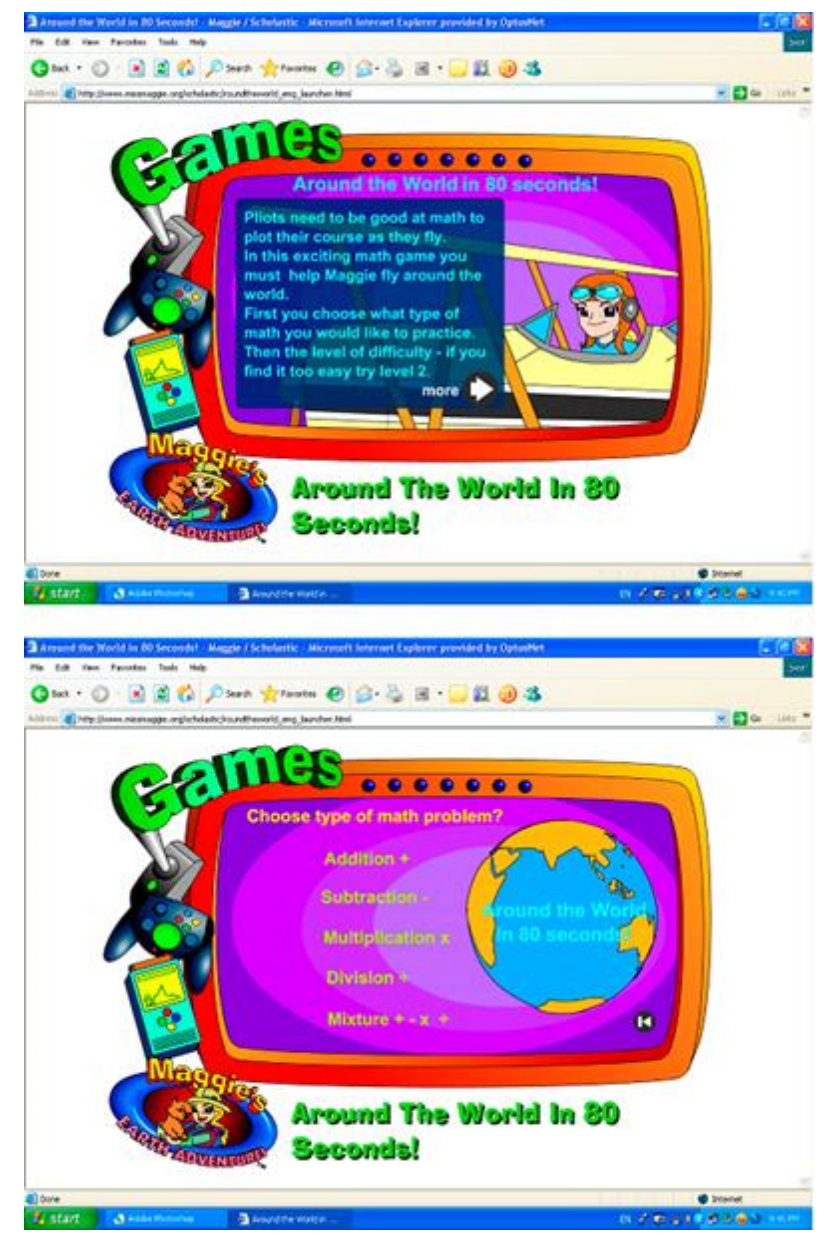

Figure 6. A page of "around the world in 60 second" 
Through the Internet, we could also find websites for online teaching resources which were already categorised into the syllabus strands. As a result, we can have access to "ready made strands”. For example:

http://www.beenleigss.eq.edu.au/requested_sites/mathsbyoutcome/index.html (Figure 7) and http://nlvm.usu.edu/en/nav/vlibrary.html (Figure 8)

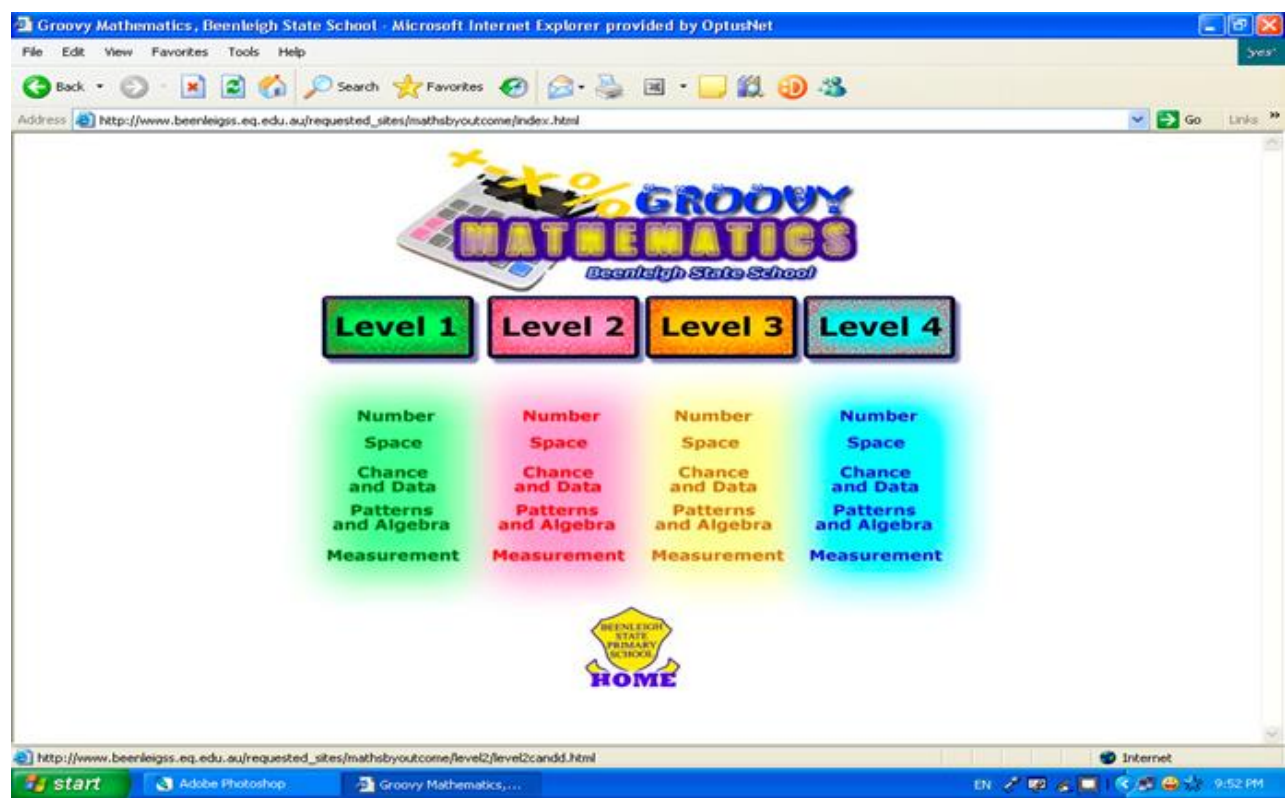

Figure 7.A page of Beenleigh mathematical website

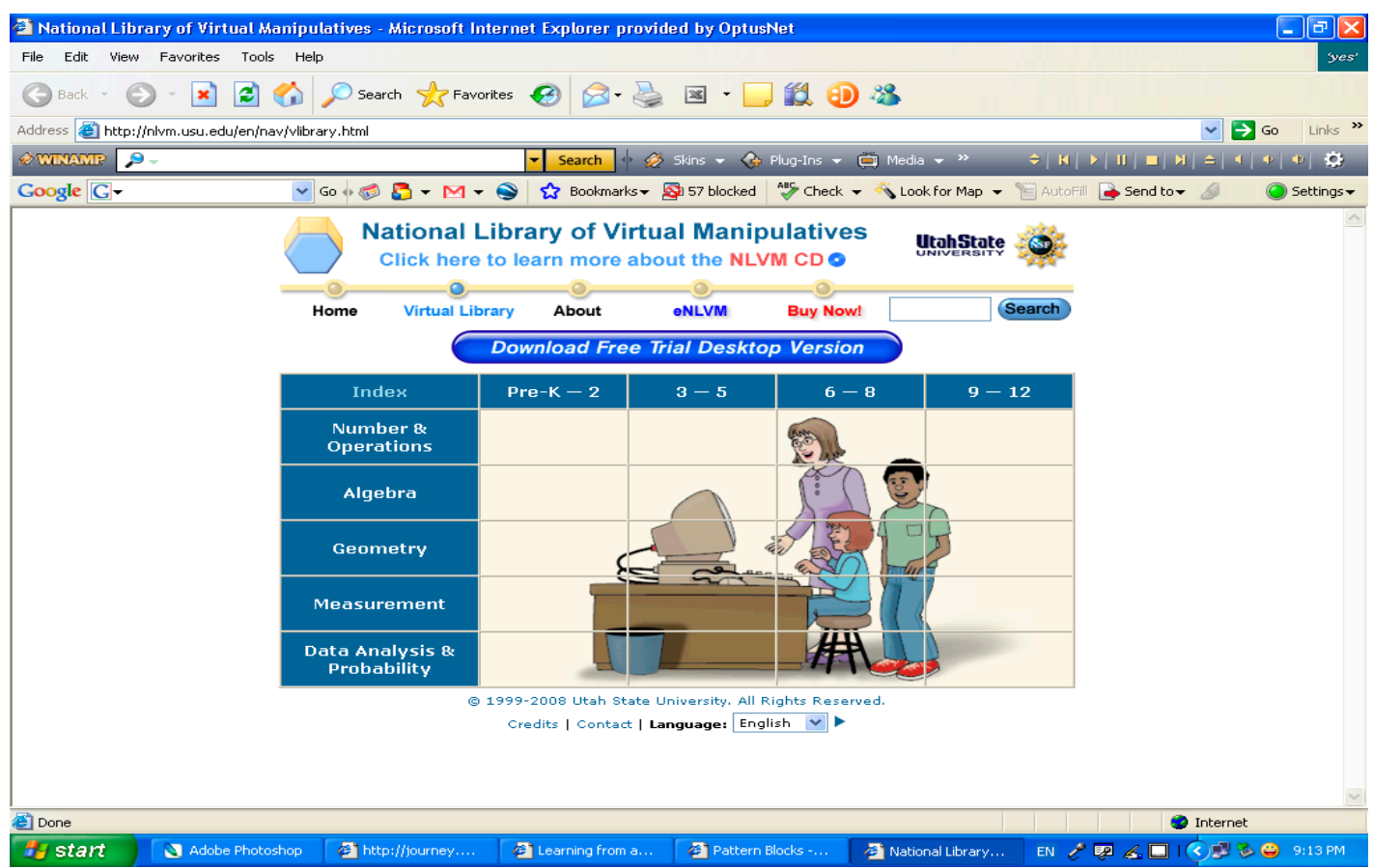

Figure 8. A page of NLVM website 


\section{Learning From A Case Of Ann: Joyful And Meaningful Learning}

The most noticeable thing about Ann's classroom was its crowded feel. There was little space for students or the teacher to move. The classroom was very open with no doors, and many people pass the classroom via the verandah. Voices from other classrooms could be heard and people who pass the classroom can be seen by the students. The tables in the classroom were arranged in three long strips with desks facing each other. Four other desks were on the verandah and were usually used for small group teaching.

In Ann's classroom with 26 students (who came from low socioeconomic status families), there were 6 computers (including one very old computer that cannot save any work), but only 2 computers were connected to the Internet. The computers were placed in one corner of the classroom, where they could be monitored by the teacher while she was helping students in other groups. Two of the six computers and one public printer were placed outside the classroom on the enclosed verandah/walkway.

The school did not have ICT staff to support the use of computers in the classroom. In one visit, I saw a student reporting a problem with a computer and Ann tried to help. Since Ann could not solve the problem at the time, she eventually turned off the computer. This problem was unresolved the next day. In a conversation with Ann, she told me that she often solved the technical problems in the classroom by herself. She added that this challenge might factor why other teachers in her school rarely used computers in their classroom for teaching.

Interviewing and observing Ann has provided evidence about how Ann encourages new ways of learning by navigating the Internet. Many students were easily finding websites since Ann had created a list of educational websites in the computer Bookmark. Using this Bookmark, Ann's students could directly use the Internet and become engaged in their own learning. Ann also encouraged and welcomed students' initiatives for using the Internet. During the classroom observations, student learning with the Internet was rarely controlled by the teacher, as happened with students in the non-computer group. However, Ann pointed out that the observed way students interacted with the Internet was not how it was at the beginning of the year, and she stated that "all students required specific assistance in using the Internet in class.” Ann further explained how

Ann's experiences using the Internet in her teaching provided her with evidence that the use of the Internet impacted positively upon students' learning. She stated that students were more engaged in learning, they were more active in asking questions and discussing ideas, they collaborated with each other, students who normally did not engage became engaged in lessons that included the Internet, students who had extra needs had the opportunity to extend their mathematics learning, and students with learning difficulties had greater opportunity to engage with the concepts at greater depth and in a range of modes.

Some of these impacts were observed. It was quite often that students in the computer group were enthusiastic in learning. Many students were seen positively interacting with the Internet, for example, by using their hands to count, there was shaking of heads, responding 
orally when solving problems, asking questions to peers or to the teacher at various times. In mathematical rotations, compared to other groups, the computer group were seen to focus on tasks quicker than non-computer groups and during the transition period in rotational activities, the movement from the non-computer group to computer group was more organised and quicker than the movement from computer group to non-computer group.

Three main reasons for using the Internet in Ann's mathematics teaching were identified, namely (1) to achieve her mathematics teaching objectives that mathematics is everywhere, a great tool to solve daily problems as well as mathematics can support cooperation/collaboration, (2) to facilitate student' learning, and (3) the belief of the important for students to have a good understanding and skill in using ICT.

Ann explained that Internet activities, for example, problem solving, math research, virtual hands-on activities, will help students gain the three objectives above. Furthermore, aligning with her philosophical beliefs about teaching and learning mathematics and individual learners (as examined in Patahuddin \& Dole, 2006), she views the Internet as assisting her to act as a facilitator, particularly in engaging learners in their own learning. As she stated:
I often find that I can engage them into some appropriate math learning related to what I am teaching, using the Internet. ..... Whereas normally, being the facilitator without the Internet is quite hard because you are there and you've got a whole class in front of you, and you can't often have a focus or enough focus ... to keep the children discussing. Whereas, I find the Internet very good for sustaining kids' discussions and focus.

Also, as a facilitator, she has found it easier to cater to diversity, and to build mathematical knowledge and processes for students, as described in the following quotations.

...you can offer extensions through the Internet. If you have children that are extra gifted who want to go into something a little further than the rest of the class... On the other side, I have used it a lot for those students who can't necessarily engage in the math that I am teaching ..... so often there are Internet activities or resources that will engage them.

Even though Ann stated many positive things about the impact of the use of technology on students' learning, and some were justified by my observations, I often think that this was particularly determined by Ann's ability in facilitating learning. The reason was I also had opportunity to observe Ann's teaching mathematics without computers. For example, students identified mathematics in a newspaper and Ann challenged them with questions to make sense of the mathematics. Students worked in groups investigating mathematical concepts using a monitor box. Students discussed what mathematics they could find through investigating the box. Some students measured the surface of the box and one student went into the box to measure the inside part. Ann's questions led them to a lively discussion between teacher and students and conversation between students and students. I also observed Ann implement several games to focus students' attention, such as, asking 
every student to stand up and be ready to catch the ball from Ann and answering Ann's questions. This was to develop the fluency in counting and to explain students' strategies in counting.

The observations on different learning scenarios (with and without the Internet) posed questions about how this dynamic learning contributed to the effective use of the Internet for learning. Focusing my observations on to the teaching with the Internet was problematic since the learning with the Internet could not be isolated from the other scenarios because students worked either individually or in pairs at the computers. However, over my extended day visits to Ann's classroom, I saw a very engaged class, where Ann asked children to elaborate their thinking at every opportunity. From discussions with Ann, and the myriad examples of incorporating the Internet into her teaching that she described, together with my observations, it appeared that Ann was a competent teacher who made the most possible use of any resources that would enhance students' learning.

\section{Concluding Comments}

The use of the Internet in this digital era seems appropriate and relevant because mathematics curriculum also highlight the importance of the use of communicating technologies in teaching mathematics, encourage context links in real life (computers and the Internet are very much part of life now, and many real life contexts are easily accessible on line), emphasis on thinking, reasoning and working mathematically, and build on conceptual knowledge. Those aspects link directly to the educational potential of the Internet and its capacities as a source of information, a means for communication, and as a site for collaboration.

With the Internet, many new ways of learning are enabled. With the Fido puzzle, students interacted with the Internet, learning about computation. With the geometric sites, students explored virtually the properties of geometric solids. With the Clock websites, students have chance to learn in different level and in different format such as matching game, recognising ways of writing the time in different ways. Those are possible if teacher's role in teaching mathematics is not one of being a transmitter or a centre of learning, but as a facilitator.

Through using the Internet, the teacher could engage students in learning and to cater to the various needs of different students. One thing to remember that the Internet cannot replace the role of the teacher as facilitator, as teachers must set up the task, pose questions, provide appropriate websites, and give feedback.

Due to its obvious potential for enhancing educational improvement (Dogruera, Eyyamb, \& Menevisab, 2011), it seems clear that Internet availability and access should be optimised. Many studies (e.g., Cuban, Kirkpatrick, \& Peck, 2001; Gibson \& Oberg, 2004), 
however, have raised the issue that the increasing amount of Internet accessibility for teachers does not necessarily indicate the effective use of the Internet by teachers.

From my study and my experiences working with teachers and learners, I argue that the Internet has potential as a medium for learning mathematics in a richer and meaningful way. However, this is determined by many factors including teachers' knowledge and their philosophical beliefs about learning and teaching. It also depends on their beliefs and expectations of learners, teacher's personal situation as well as their own knowledge and beliefs about mathematics and technology. In addition, technology does not necessarily mean student engagement. Internet use could enhance student motivation, but also the fact that it does not always lead to student engagement, motivation and learning.

\section{References}

Alagic, M. (2003). Technology in the Mathematics Classroom: Conceptual Understanding. Journal of Computers in mathematics and Science Teaching, 22(4), 381-399.

Ameis, J. A., \& Ebenezer, J. V. (2000). Mathematics on the Internet. A resource for K-12 Teachers. New Jersey: Prentice-Hall, Inc.

Byerly, G., \& Brodie, C. S. (2004, April). Math magic on the web. School Library Media Activities Monthly, 20, 35-36.

Clark, J. (2000). Collaboration tools in online learning. the Journal of Asynchronous Learning Networks (JALN), 4(1), 7-14.

Crawford, C., \& Evelyn, B. (2003). Integrating Internet-based mathematical manipulatives within a learning environment. Journal of Computers in Mathematics and Science Teaching, 22(2), 169-180.

Cuban, L., Kirkpatrick, H., \& Peck, C. (2001). High access and low use of technologies in high school classrooms: Explaining an apparent paradox. American Educational Research Journal, 38(4), 813-834.

Dogruera, N., Eyyamb, R., \& Menevisab, I. (2011). The use of the internet for educational purposes. Procedia - Social and Behavioral Sciences, 28, 606 - 611.

Engelbrecht, J., \& Harding, A. (2005). Teaching undergraduate mathematics on the Internet Part 2: Attributes and possibilities. Educational Studies in Mathematics, 58(2), 253 276.

Ernawati, A., \& Patahuddin, S. M. (2009, 5 Desember). Pemanfaatan internet dalam mempersiapkan guru mengajar di kelas RSBI. Paper presented at the Seminar Nasional Matematika dan Pendidikan Matematika Jurusan Pendidikan matematika FMIPA UNY, Yogyakarta.

Frid, S. (2002). Engaging primary students in working mathematically within a virtual enrichment program. [Journal-articles]. Mathematics Education Research Journal, 14(1), 60-79.

Gibson, S., \& Oberg, D. (2004). Visions and realities of Internet use in schools: Canadian perspectives. British Journal of Educational Technology, 35(5), 569-585.

Glavac, M. (2004). Notable sites for teachers [www.schoolhistry.co.uk] [www.sciencemaster.com] [www.laerningbox.com/i_index.htm]. Teach Retrieved November 16, 2004, from http://proquest.umi.com/pqdweb

Loong, E. Y.-K. (2012). Web-based Mathematics: Student Perspectives. Retrieved from http://www.merga.net.au/documents/MERGA33_Loong.pdf

Moor, J., \& Zazkis, R. (2000). Learning mathematics in a virtual classroom: Reflection on experiment. Journal of Computers in Mathematics and Science Teaching, 19(2), 89-113. 
NCTM. (2005). Geometric solid Retrieved August, 2005, from http://illuminations.nctm.org/ActivityDetail.aspx?ID=70

Newell, G., Wilsman, M., Langenfeld, M., \& McIntosh, A. (2002). Online professional development: Sustained learning with friends. Teaching Children Mathematics, 8(9), 505.

Patahuddin, S. M. (2007). Encouraging a novice teacher to use the Internet in primary school mathematics. In L. C. Sam (Ed.), The 4th East Asia Regional Conference on Mathematics Education (EARCOME 4) (pp. 259-266). George Town, Penang: School od Educational Studies, Universiti Sains Malasyia.

Patahuddin, S. M., \& Dole, S. (2006). Using the internet in teaching mathematics in primary school. In P. Grootenboer, R. Zevenbergen \& M. Chinnappan (Eds.), The 29th Annual Conference of the Mathematics Education Research Group of Australia (MERGA) (Vol. 2, pp. 400 - 407). Canberra: MERGA Inc.

Patahuddin, S. M., \& Rokhim, A. F. (2009). Websites of online mathematical games for joyful mathematics learning (Website permainan matematika online untuk belajar matematika secara menyenangkan). Jurnal Pendidikan Mtematika, 3(2).

Patahuddin, S. M., Rokhmah, S., \& Nur, M. (2010). Developing mathematics worksheets to facilitate learning using the internet for International-based schools. Paper presented at the Simposium Nasional Penelitian dan Inovasi Pendidikan Tahun 2010, Jakarta.

Rokhim, A. F., \& Patahuddin, S. M. (2010). Online mathematical game to develop student's critical thinking. Paper presented at the Seminar Nasional Matematika dan Pendidikan Matematika 2010, Malang.

Rokhmah, S., Patahuddin, S. M., \& Nur, M. (2010). Minds-on, hands-on, dan virtual handson dalam pembelajaran matematika. Paper presented at the Seminar Nasional Matematika dan Pendidikan Matematika FKIP Universitas Muhammadiyah Malang. Tema: Peran Matematika, Pendidikan Matematika serta Terapannya dalam Perkembangan Ilmu Pengetahuan dan Teknologi (IPTEK), Malang.

Wiske, M. S., Sick, M., \& Wirsig, S. (2001). New technologies to support teaching for understanding. International Journal of Educational Research, 35(5), 483-501.

Acknowledgement: I presented some parts of this paper at The Annual Conference of the Mathematics Education Research Group of Australia (MERGA) in Canberra in 2006. 